\title{
Propiedades acústicas de los paneles de carrizo
}

\section{Acoustic properties of reed panels}

\author{
C. Díaz ${ }^{(*)}$, M. Jiménez ${ }^{(*)}$, M. Á. Navacerrada ${ }^{(*)}$, A. Pedrero(*)
}

Recepción/Received: 14-VI-10

Aceptación/Accepted: 30-IX-10

Publicado online/Online publishing: 17-XI-10

\section{RESUMEN}

El carrizo es una especie vegetal, parecida a la caña común, que se encuentra ampliamente distribuida en la superficie terrestre. Es un material ecológico y sostenible de bajo coste, estéticamente aceptable, fácil de obtener y colocar, que permite generar diferentes sistemas constructivos.

En este trabajo se analizan las propiedades acústicas de los paneles de carrizo en lo referente a la absorción acústica y al aislamiento acústico a ruido aéreo, para ello se han aplicado los procedimientos de las normas EN ISO correspondientes. De los resultados experimentales obtenidos se concluye que los paneles de carrizo son unos sistemas constructivos adecuados para el control del sonido reverberante en un recinto y que los valores del índice de reducción acústica de paneles de diferentes espesores o en combinación con tableros de partículas de madera muestran la posibilidad de utilizarlos en la edificación como elemento de fachada, en cubiertas de edificios y particiones interiores.

Palabras clave: carrizo, construcción sostenible, absorción sonora, aislamiento a ruido aéreo.

\section{SUMMARY}

Reed is a plant species very similar to common cane which is widespread all over the Earth. It is an ecological and sustainable material which is low-cost, aesthetically attractive, easy to obtain and install, and can be used in different construction systems.

This work analyses the acoustic properties of reed panels from the point of view of sound absorption and sound insulation against airborne noise, according to the corresponding EN ISO standards. The experimental results obtained point to the conclusion that reed panels are suitable construction systems for controlling reverberant sound within a space, and that the sound reduction index values for different thicknesses of reed panels, or reed panels used in combination with wood particle boards, demonstrate the possibility of using them in construction as an element on the facades and roofs of buildings and for interior partitions.

Keywords: reed, sustainable construction, sound absorption, airborne sound insulation.

\section{INTRODUCCIÓN}

El carrizo es una planta perenne perteneciente a la familia de las gramíneas o Poáceas, habitual en los lugares húmedos en las regiones templadas y tropicales en la tierra. La

\section{INTRODUCTION}

Reed, a perennial grass of the Gramineae (or Poaceae) family, grows in moist areas in both temperate and tropical climates. Ranging from 1.5 to 4 metres high, its

(*) Universidad Politécnica de Madrid (Madrid, España). 
altura de la planta varía entre 1,5 y 4 metros, alcanzando un diámetro máximo de $2 \mathrm{~cm}$. Está formada por una sucesión de nudos y entrenudos perfectamente diferenciados. La estructura microscópica del carrizo muestra la gran cantidad de poros cerrados en su configuración. Su densidad cuando está seco es aproximadamente de $160 \mathrm{~kg} / \mathrm{m}^{3}$.

Es una planta que produce mucha biomasa que es conveniente cosechar periódicamente para eliminar el exceso de materia orgánica. La composición química del carrizo en porcentaje es: celulosa (42,5-45\%), lignina (22-24\%), pentosanos $(24-27 \%)$, ceras grasa y resinas $(1-5,6 \%)$ y sustancias minerales (4,7-5,6\%). Es resistente a las heladas y un buen aislante térmico, debido a la gran cantidad de huecos llenos de aire de los tallos. Su conductividad térmica es $\lambda=0,055 \mathrm{~W} / \mathrm{m}$.K. Los tallos de carrizo presentan excelente resistencia a la flexión y a la tracción. Es un material hidrofóbico y con inflamabilidad normal. Tiene una excelente durabilidad, como demuestra su utilización como cubierta vegetal en países de Europa central.

Como material de construcción es uno de los materiales naturales más antiguos utilizados y en la actualidad se utiliza como mallas de refuerzo, en forma de paneles en particiones interiores, fachadas, cubiertas (espesores $35-40 \mathrm{~cm}$ ), etc. El carrizo se utiliza también junto con otros materiales como encofrado, como pantalla en vallas y verjas, como base para el yeso en la construcción de particiones interiores, o recubierto con barro. Con el carrizo triturado se pueden realizar paneles granulares con un aglutinante.

En una construcción sostenible, los paneles de carrizo son sistemas ecológicos, fabricados mediante recursos renovables. Cumplen las funciones de un material aislante térmico y acústico, son mecánicamente resistentes en la construcción de paredes y techos y estéticamente aceptables. Los paneles se producen mediante compactación de los tallos de carrizo en diferentes tamaños y se unen mediante alambre galvanizado de diámetro entre 1,5 y $2 \mathrm{~mm}$. Los paneles se pueden combinar perfectamente con yeso, cal y arcilla.

En la Figura 1 se muestran algunos paneles de carrizo utilizados en los ensayos acústicos, en ellos se observa que debido a las irregularidades de los diámetros de los tallos, es un sistema permeable. En la sección transversal se comprueba la existencia de los huecos en el espacio entre nudos. stem is no more than $2 \mathrm{~cm}$ in diameter and comprises a series of clearly differentiated nodes and internodal zones. Microscopic studies reveal a structure with a great many closed pores. Its dry density is approximately $160 \mathrm{~kg} / \mathrm{m}^{3}$.

This plant produces large amounts of biomass which should be harvested from time to time to eliminate excess organic matter. Its chemical composition is as follows: $42.5-45 \%$ cellulose, 22-24\% lignin, 24-27\% pentosan, 1.5-6\% wax, fat and resin and $4.7-5.6 \%$ minerals. It is freeze-resistant and the large number of air-filled voids in its stems make it a good thermal insulator. Reed has a thermal conductivity of $\lambda=$ $0.055 \mathrm{~W} / \mathrm{m} . \mathrm{K}$. Its stems, which exhibit high bending and tensile strength, are water-repellent and medially flammable. Their excellent durability is attested to by their use as a roofing material in Central Europe.

It has a very long history as a construction material. Today it is woven into a mesh to strengthen panels for partition walls, façades and roofs (35-40 cm thick). Reed is likewise used as one of the components in masonry formwork, as a screen in fences and as a substrate for plaster in building partitions. It may also be mixed with mud. Mixed with a binder, crushed reed can be made into granular panels.

Reed panels are green systems manufactured with renewable resources and ideal for sustainable construction. They are good thermal and acoustic insulators, characterised by high mechanical strength and aesthetically apt for wall and ceiling construction. The panels comprise flat bundles of different diameters of reed stems bound by galvanised steel wire from 1.5 to $2 \mathrm{~mm}$ in diameter. They can be combined with plaster, lime or clay.

The reed panels depicted in Figure 1 were used in the present acoustic trials. Note that the irregularity of the stem diameters makes the panels permeable. An examination of the cross-section reveals the existence of internodal voids.

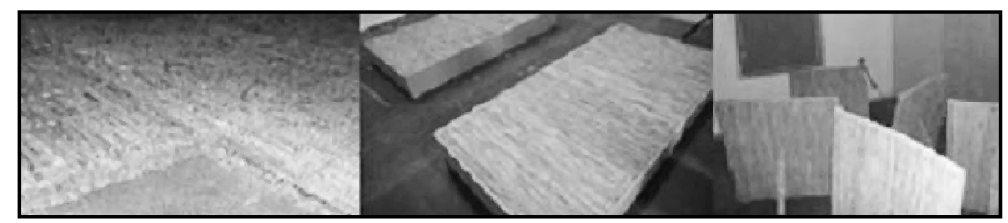

Figura 1. Fotografía de los paneles de carrizo medidos y de su sección transversal. Figure 1. Reed panels measured and their cross-section. 
En este trabajo se analizan las propiedades acústicas de los paneles de carrizo en lo referente a la absorción acústica y al aislamiento acústico a ruido aéreo, para ello se han aplicado los procedimientos de las normas EN ISO 140-3:1995 y EN ISO 354:2003. Los equipos utilizados en las mediciones acústicas están fabricados por Brüel\&Kjaer (analizadores acústicos modelo 3560 C, fuentes sonoras omnidireccionales, micrófonos giratorios, software de procesado, etc.). La precisión de los equipos de medida se verifica periódicamente en laboratorios de calibración certificados. En las cámaras de ensayo, durante las mediciones acústicas la temperatura fue $20^{\circ} \mathrm{C} \pm 2{ }^{\circ} \mathrm{C}$ y la humedad relativa $\mathrm{HR}=60 \pm 5 \%$.

\section{ABSORCIÓN ACÚSTICA}

Ensayos realizados del coeficiente de absorción acústica a incidencia normal de diferentes configuraciones de paneles de carrizo han mostrado que es un buen absorbente acústico a medias y altas frecuencias (1). Los ensayos de absorción acústica objeto de este trabajo se han realizado en un recinto del Laboratorio de Acústica de la ETS de Arquitectura de la UPM de volumen $65 \mathrm{~m}^{3}$, que no cumple los requerimientos de la Norma EN ISO 354:2003 (2), en cuanto al volumen y área de absorción sonora equivalente máxima. Por otra parte, las muestras de ensayo tienen un área menor de $10 \mathrm{~m}^{2}$. Las mediciones de los tiempos de reverberación se han realizado de acuerdo con los protocolos de la citada Norma. Los resultados de las mediciones del coeficiente de absorción acústica a bajas frecuencias no son precisos debido al pequeño volumen del recinto de ensayo y que el campo sonoro no es lo suficientemente difuso, sin embargo los resultados obtenidos pueden ser utilizados con fines de comparación.

Los coeficientes de absorción sonora se han obtenido mediante montajes de tipo A, E y J, descritos en el Anexo $B$ de la Norma citada previamente. La Figura 2 muestra la colocación de las muestras en los diferentes montajes.

En los montajes Tipo A, las muestras se han colocado directamente en el suelo del recinto de ensayo, ocupando $5 \mathrm{~m}^{2}$ del mismo, los bordes de las muestras no estaban cubiertos. En estos montajes, los paneles de carrizo se comportan como una combinación de resonadores en serie y paralelo, formados por tubos cerrados por los dos extremos y tubos cerrados por un extremo y abiertos por
This study analysed the acoustic properties of reed panels such as sound absorption and insulation against air-borne noise following the procedures laid down in European standards EN ISO 140-3:1995 and EN ISO 354:2003. Brüel\&Kjaer model 3560 C data collection hardware was used (along with omni-directional sound sources, revolving microphones and processing software). The precision of the measuring devices used is periodically verified in certified calibration laboratories. The temperature in the test chamber during the sound trials was $20 \pm 2{ }^{\circ} \mathrm{C}$ and the relative humidity was $60 \pm 5 \%$.

\section{SOUND ABSORPTION}

Tests conducted to determine normal incidence sound absorption coefficients have shown that various configurations of reed panels make good acoustic absorbents at medium and high frequencies (1). The present acoustic absorption tests were conducted in a 65$\mathrm{m}^{3}$ room in the Madrid School of Architecture's acoustics laboratory that did not meet the volume and maximum equivalent sound absorption area requirements laid down in European standard EN ISO 354:2003 (2). The area of the test samples, in turn, was under $10 \mathrm{~m}^{2}$. The reverberation times were measured as prescribed in the aforementioned standard. While the low frequency sound absorption coefficient measurements were imprecise due to the scant volume of the room where the tests were conducted and because the sound field was not sufficiently diffuse, the findings can nonetheless be used for the purposes of comparison.

The sound absorption coefficients were measured with set-ups type A, E and $J$ described in Annex $B$ to the standard. The position of the samples in the various setups is depicted in Figure 2.

In type $A$ set-ups, $5 \mathrm{~m}^{2}$ of samples with non-sealed edges were positioned on the floor of the test room. In these set-ups, the reed panels behaved like a combination of series and parallel resonators consisting of tubes closed at one or both ends. Five-, 10- and 15$\mathrm{cm}$ thick samples were tested. The findings in Figure 3 show that at low and medium frequencies, the sound

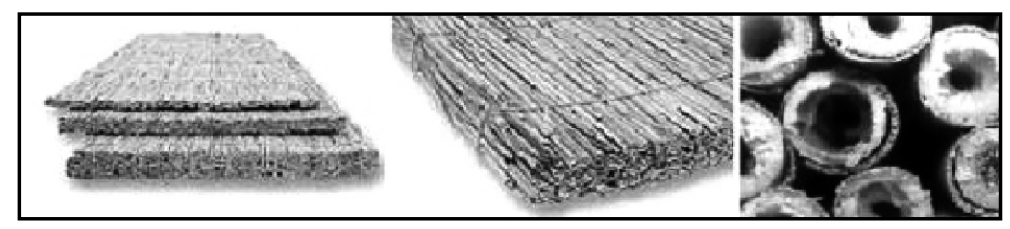

Figura 2. Fotogragía de la colocación de los paneles de carrizo para la medida del coeficiente de absorción sonora. Figure 2. Reed panels positioned to measure the sound absorption coefficient. 
el otro. Se han realizado los ensayos con muestras de espesor: 5, 10 y $15 \mathrm{~cm}$ respectivamente. En la Figura 3 se muestran los resultados obtenidos. Se comprueba que a medida que aumenta el espesor de los paneles, se incrementa el coeficiente de absorción acústica a frecuencias medias y bajas. A partir de la banda de frecuencia central de $1 \mathrm{kHz}$, el espesor de los paneles no influye en los valores del coeficiente de absorción acústica. absorption coefficient rose with panel thickness. At centre frequency bands of $1 \mathrm{kHz}$ or higher, however, panel thickness had no impact on the sound absorption coefficient values.

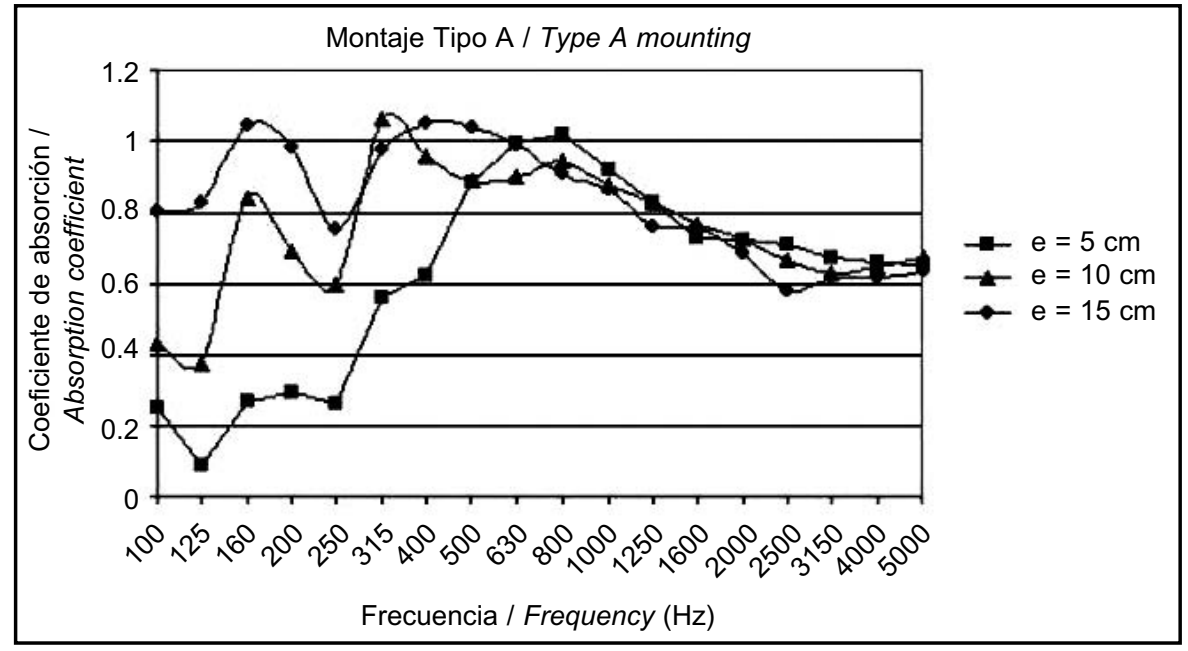

Figura 3. Efecto del espesor en el coeficiente de absorción sonora. Figure 3. Effect of panel thickness on the sound absorption coefficient.

En el montaje Tipo $\mathrm{E}$, se han colocado paneles de carrizo (área de la muestra: $4 \mathrm{~m}^{2}$ ) de espesor $5 \mathrm{~cm}$ con una cámara de aire de $20 \mathrm{~cm}$, simulando un techo suspendido. Los resultados experimentales se muestran en la Figura 4. Por las características de la cámara de ensayo, los valores obtenidos en las cuatro primeras bandas de frecuencia, son menos precisos.
In the type $E$ set-up, $5 \mathrm{~cm}$ thick reed panels (sample area $4 \mathrm{~m}^{2}$ ) were positioned over a $20 \mathrm{~cm}$ air chamber to simulate a suspended ceiling. The findings are shown in Figure 4. Because of the characteristics of the test chamber, the values obtained in the first four frequency bands were less precise.

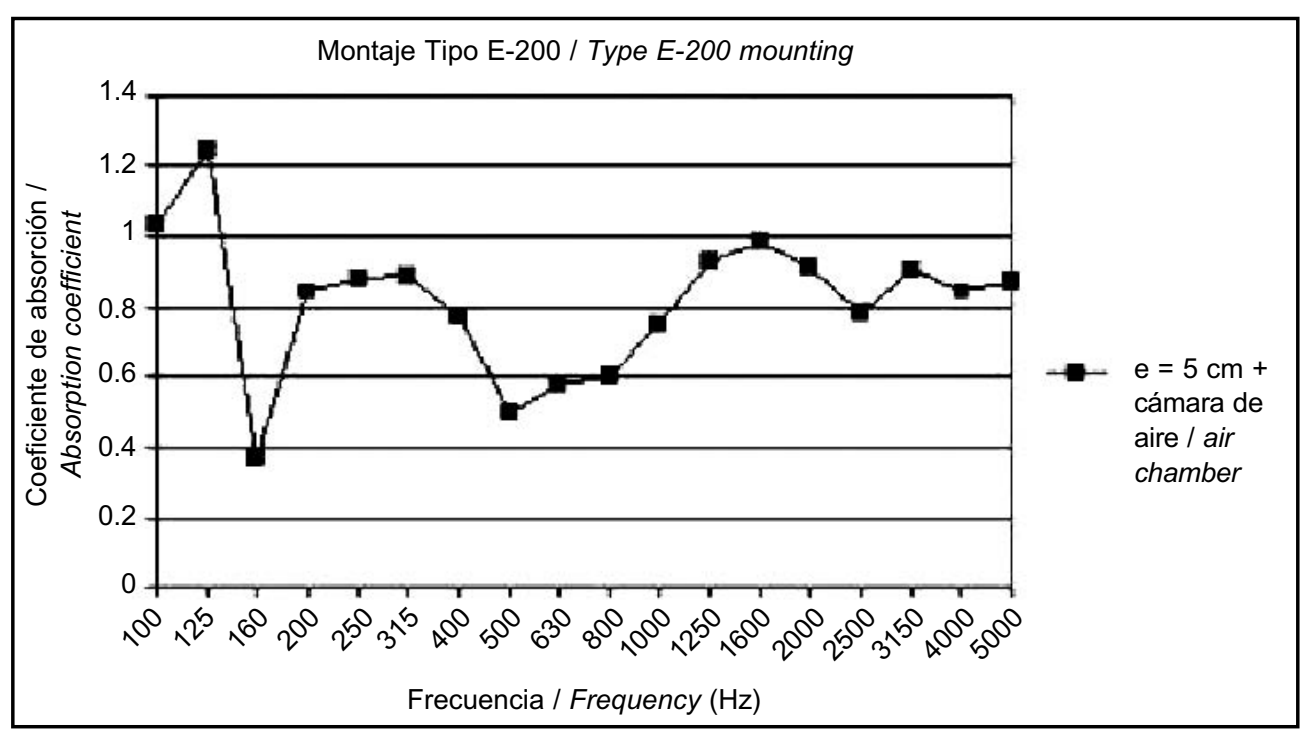

Figura 4. Coeficiente de absorción sonora de los paneles de carrizo simulando un techo suspendido. Figure 4. Sound absorption coefficients for reed panels simulating a suspended ceiling. 


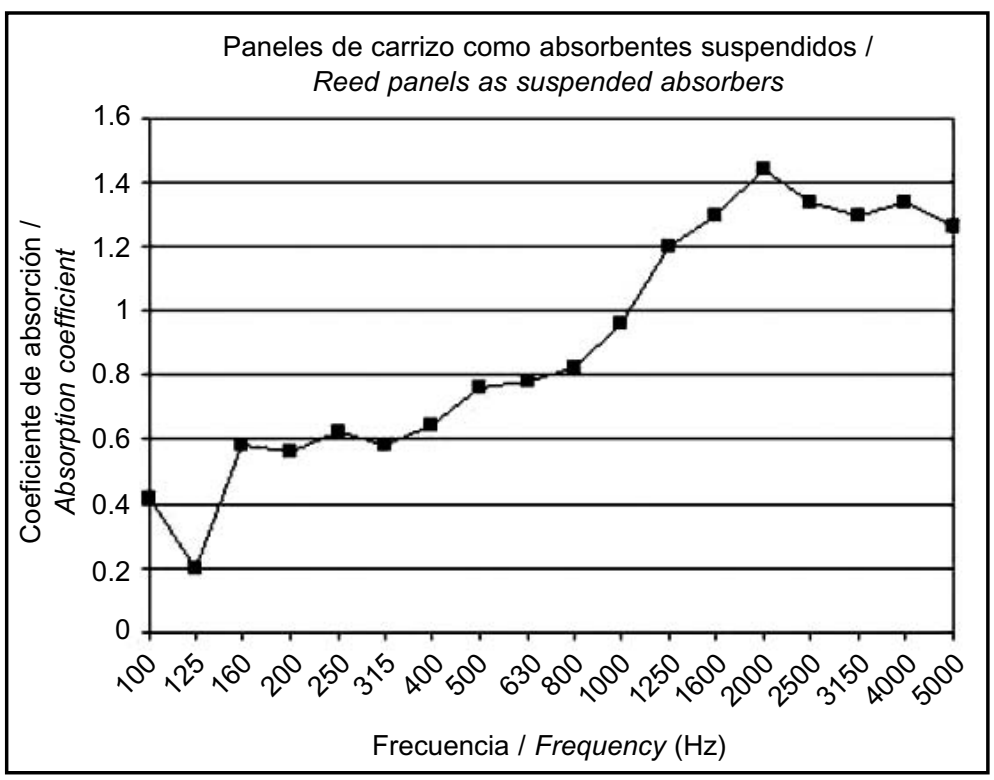

Figura 5. Área de absorción acústica equivalente de los paneles de carrizo en posición vertical.

Figure 5. Equivalent sound absorption area of vertical reed panels.

En el montaje Tipo J, se han colocado de forma aleatoria 5 paneles de carrizo de espesor $5 \mathrm{~cm}$, perpendiculares al suelo del recinto, como dispositivos absorbentes suspendidos. Los valores del área de absorción acústica equivalente se muestran en la Figura 5.

Los resultados de los ensayos realizados muestran que los paneles de carrizo tienen una buena absorción acústica a medias y altas frecuencias. El uso de paneles de carrizo como sistema de acabado de las superficies interiores de un recinto (paredes, techos) puede ser eficaz para reducir los niveles de presión sonora en el campo reverberante y controlar el tiempo de reverberación del recinto.

\section{AISLAMIENTO ACÚSTICO A RUIDO AÉREO}

Los ensayos de aislamiento a ruido aéreo se han realizado en las cámaras de transmisión horizontal del Laboratorio de Acústica de la ETS de Arquitectura de la UPM (3). Para calcular el Índice de Reducción Acústica, R, de diferentes combinaciones de paneles de carrizo y tableros de MDF, en la pared separadora de las dos cámaras se realizó una abertura de $1 \mathrm{~m}^{2}$, donde se colocaron los diferentes sistemas constructivos objeto de ensayo, los paneles de carrizo manufacturados generalmente tienen dimensiones de $1 \mathrm{~m} \times 1 \mathrm{~m}$. Los ensayos se han efectuado de acuerdo con la Norma EN ISO 140-3:1995 (4) en bandas de $1 / 3$ de octava en el rango de frecuencias centrales de 100 a $5 \mathrm{kHz}$, y los resultados globales $\mathrm{R}_{\mathrm{w}}$ (C; $C_{t r}$ ) se han calculado según la Norma EN ISO 717-1:1996 (5). La Figura 6 muestra algunos de los montajes. Aunque el área de las muestras objeto de ensayo no son
In the type $\mathrm{J}$ set-up, five $5-\mathrm{cm}$ thick reed panels were hung vertically in random positions in the room, like suspended absorbers. The values of the equivalent sound absorption area are shown in Figure 5.

The tests findings showed that the reed panels exhibited good sound absorption at medium and high frequencies. The use of reed panels as a finish on walls and ceilings in a room may suffice to reduce sound pressure levels in a reverberant field and control reverberation times in the room.

\section{ACOUSTIC INSULATION AGAINST AIR-BORNE NOISE}

Air-borne noise insulation tests were conducted in horizontal transmission chambers at the Madrid School of Architecture's Acoustic Laboratory (3). The sound reduction index, $R$, for different combinations of reed panels and MDF (medium density fibreboard) was calculated by making a $1 \mathrm{~m}^{2}$ opening in the partition panel between the two chambers where the construction systems to be tested were placed, inasmuch as the standard dimensions for reed panels are $1 \times 1 \mathrm{~m}$. The tests were conducted as described in European standard EN ISO 140-3:1995 (4) in 1/3-octave bands in the centre range of frequencies, 100 to $5 \mathrm{kHz}$. The weighted $R_{W}$ (C; $C_{t r}$ ) values were found as set out in European standard EN ISO 717-1:1996 (5). Two of the panels used are depicted in Figure 6. Although the area of the samples tested was not EN ISO 1403-compliant, the 


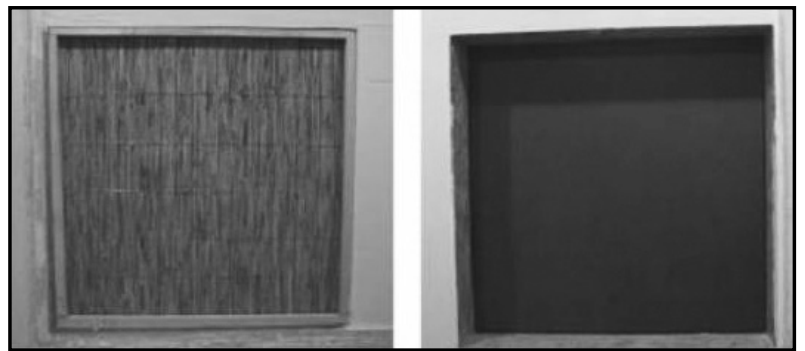

Figura 6. Fotografía de la colocación de los paneles de carrizo y de los tableros MDF para las medidas de aislamiento. Figure 6. Reed and MDF panels for insulation measurements.

conformes a los requerimientos de la Norma EN ISO 140-3, puede esperarse que los datos de medida obtenidos proporcionarán algunas claves sobre el aislamiento acústico a ruido aéreo de los sistemas estudiados.

La Figura 7 muestra los resultados medidos del Índice de Reducción Acústica $\mathrm{R}$, en $\mathrm{dB}$, en función de la frecuencia, de paneles de carrizo secos con los bordes sellados. Los espesores de las muestras ensayadas varían entre 5 y 30 $\mathrm{cm}$. Como se observa en la Figura 7, cuando las muestras tienen espesores a partir de $10 \mathrm{~cm}$, el Índice de Reducción Acústica aumenta con la masa y con la frecuencia. En el caso de un panel de carrizo de espesor $5 \mathrm{~cm}$, la curva del Índice de Reducción Acústica presenta la forma típica de los materiales porosos. Es posible que en este caso, la transmisión del sonido se realice de forma predominante a través de los huecos de los tallos del carrizo, mientras que a medida que el espesor se incrementa, disminuye la transmisión por los huecos y aumenta el efecto de la masa de los paneles.

En la Tabla 1 se muestran los valores de la magnitud global Índice ponderado de Reducción Acústica $R_{w}$ y sus términos data measured may be expected to provide some insight into the capacity of the systems studied to insulate a room from air-borne noise.

Figure 7 shows the sound reduction index $(R)$ findings in $d B$ for dry reed panels with sealed edges. The samples tested ranged from 5 to $30 \mathrm{~cm}$ thick. As Figure 7 shows, for thicknesses of $10 \mathrm{~cm}$ and greater, sound reduction rose with mass and frequency. The sound reduction index curve for $5-\mathrm{cm}$ thick reed panels exhibited a shape typical of the curve for porous materials. In such thin panels, sound may have been transmitted predominantly across the voids in the reed stems, whereas in thicker panels, such predominance would wane as the prevalence of panel mass grew.

Table 1 gives the weighted sound reduction index $\left(R_{W}\right)$ values and their spectral adaptation terms for different

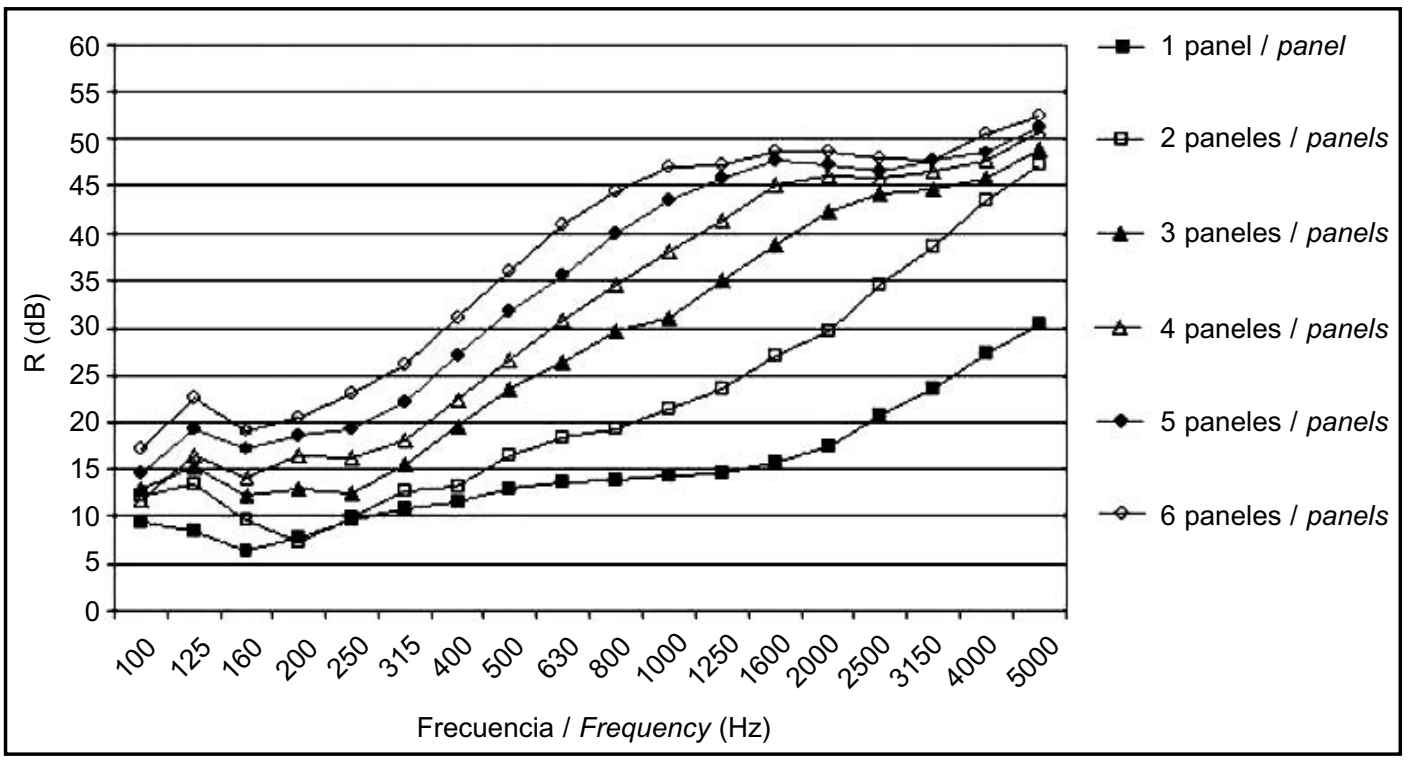

Figura 7. Índice de Reducción Acústica $\mathrm{R}$ de paneles de carrizo de diferente espesor con los bordes sellados. Figure 7. Sound reduction index, $R$, for different thicknesses of reed panels with sealed edges. 
Tabla 1 / Table 1

Valores del Índice Ponderado de Reducción Acústica $R_{\mathrm{w}}$ y sus términos de adaptación espectral para los paneles de carrizo de diferentes espesores.

Weighted sound reduction index $\left(R_{w}\right)$ values and their spectral adaptation terms for different thicknesses of reed panels.

\begin{tabular}{|c|c|c|c|}
\hline \multirow{2}{*}{$\begin{array}{c}\text { Densidad Superficial / } \\
\text { Surface density }\left(\mathbf{k g} / \mathbf{m}^{2}\right)\end{array}$} & $\begin{array}{c}\text { Espesor panel / } \\
\text { Panel thickness } \mathbf{( c m )}\end{array}$ & & \multicolumn{2}{|c}{$\begin{array}{c}\text { Paneles carrizo con bordes sellados I } \\
\text { Reed panels with sealed edges }\end{array}$} \\
\cline { 2 - 4 } & 5 & $\mathbf{R}_{\mathbf{W}}\left(\mathbf{C} ; \mathbf{C}_{\mathrm{tr}}\right)(\mathbf{d B})$ & $15(0 ; 2)$ \\
\hline 8 & 10 & $20(0 ;-3)$ & $20(1 ;-3)$ \\
\hline 16 & 15 & $26(-1 ;-5)$ & $26(0 ;-5)$ \\
\hline 24 & 20 & $30(-2 ;-6)$ & $30(-1 ;-6)$ \\
\hline 32 & 25 & $33(-1 ;-6)$ & $33(0 ;-6)$ \\
\hline 40 & 30 & $36(-1 ;-6)$ & $36(0 ;-6)$ \\
\hline 40 & & & \\
\hline
\end{tabular}

de adaptación espectral para los paneles de carrizo de diferentes espesores. De los valores obtenidos se puede hallar una relación entre el valor global $R_{w}$ y la masa por unidad de superficie del carrizo $\mathrm{m}^{\prime}$. Los valores obtenidos se deberán redondear al número entero más próximo [1]: thicknesses of reed panels. These data can be used to find the relationship between the weighted value, $R_{W}$ and the surface density of reed, $m^{\prime}$. The result of this calculation should be rounded to the closest integer [1]:

$$
R_{w}=27.5 \lg \left(\frac{m^{\prime}}{m_{0}^{\prime}}\right)-11.5 \mathrm{~dB} ; \quad m_{0}^{\prime}=1 \mathrm{~kg} / \mathrm{m}^{2}
$$

Se ha calculado una correlación múltiple para determinar la relación entre el Índice de Reducción Acústica R como función de su masa por unidad de superficie $m^{\prime}$ y la frecuencia, f. La correlación obtenida es [2]:
Multiple correlation analysis was performed to determine the relationship among the sound reduction index, $R$, reed surface density, $m^{\prime}$, and frequency, $f$. The resulting expression was [2]:

$$
R=29 \lg \left(m^{\prime}\right)+22 \lg (f)-74 d B
$$

La Figura 8 muestra, para un sistema de tres paneles, la comparación de los resultados medidos, los calculados con la correlación obtenida, y con la ley de masa semiempírica a incidencia de campo. Debido a la constitución y configuración de los paneles esta ley semiempírica no ajusta bien con los resultados experimentales [3].
Figure 8 compares the experimental sound reduction index values for a three-panel unit to the results calculated from the above expression for the same unit, and to the semi-empirical mass law. Given panel composition and design, the semi-empirical law did not provide a good fit to the experimental findings [3].

$$
R_{f} \approx 20 \cdot \log \left(m^{\prime} f\right)-47,4 \quad d B
$$

Los resultados obtenidos en los ensayos realizados con los paneles de carrizo respecto a su absorción acústica e Índice de Reducción Acústica muestran diferentes usos de los paneles de carrizo y como mejorar su aislamiento a ruido aéreo.

Unos usos posibles de los paneles de carrizo pueden ser como particiones interiores, fachadas, cubiertas y barreras acústicas tanto en exteriores como en interiores de recintos. Por ejemplo, cuando una barrera acústica se coloca en un recinto, afectará al campo sonoro directo de la fuente sonora y al campo sonoro reverberante debido a la absorción de las superficies de la barrera. El uso de paneles de carrizo en paredes, techos y como barrera acústica puede ser útil para mejorar la privacidad de la palabra por ejemplo en oficinas de planta abierta, restaurantes, etc.
Pursuant to the sound absorption and sound reduction index findings, reed panels are apt for a number of uses. The results also suggest ways to improve their insulation capacity against air-borne noise.

The possible uses for reed panels include partition walls, façades, roofs and both outdoor and indoor sound barriers. When a sound barrier is positioned in a room, for instance, absorption at the barrier surface affects both the direct and reverberant sound fields generated by the source. Reed panels may be used in walls, ceilings and as sound barriers to enhance the privacy of conversations in open plan offices and restaurants, for instance. 


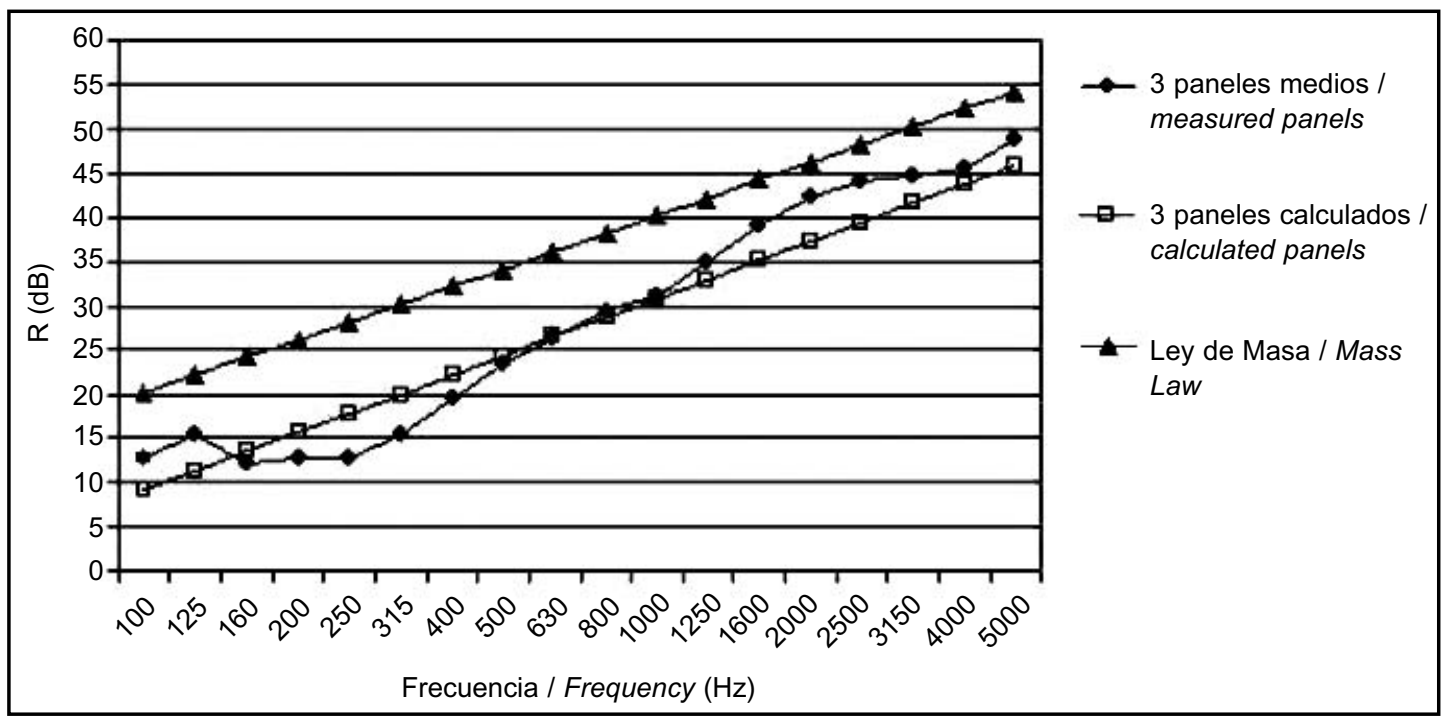

Figura 8. Comparación entre los resultados medidos y los calculados del Índice de Reducción Acústica R de un sistema de tres paneles.

Figure 8. Comparison between the measured and calculated sound reduction index, $R$ (mean of three panels).

Una posibilidad de mejora del aislamiento acústico a ruido aéreo de los paneles de carrizo es utilizarlos conjuntamente con otros productos derivados de la madera tales como los tableros de densidad media, MDF. De esta forma, estos sistemas se podrían utilizar como particiones interiores, fachadas y cubiertas, con un adecuado aislamiento acústico a ruido aéreo en recintos habitables protegidos. Se han elegido los tableros de MDF, por ser muy versátiles en la construcción, además aportan a los paneles de carrizo un aumento de la resistencia mecánica y disminuyen la permeabilidad al aire y al agua del sistema. Los paneles DMF utilizados en los ensayos tienen un espesor de $16 \mathrm{~mm}$ y su conductividad térmica es $\lambda=0,18 \mathrm{~W} / \mathrm{m}$. K.

A continuación se exponen y analizan los resultados obtenidos en los ensayos acústicos realizados con diferentes combinaciones de paneles de carrizo y paneles DMF. En la Figura 9 se comparan los resultados de los Índices de Reducción Acústica de los siguientes sistemas:1) tablero DMF; 2) tablero DMF trasdosado con un panel de carrizo de espesor $5 \mathrm{~cm}$; 3) tablero DMF con una lámina asfáltica (espesor 2 milímetros y masa por unidad de superficie de $3,5 \mathrm{~kg} / \mathrm{m}^{2}$ ) encolada al tablero; 4) dos tableros DMF separados $5 \mathrm{~cm}$, en cuya cámara se ha colocado un panel de carrizo. Los sistemas 2, 3 y 4 mejoran ampliamente el Índice de Reducción Acústica del sistema 1 y reducen el efecto de coincidencia del tablero de partículas, cuya frecuencia crítica de coincidencia es próxima a $1.700 \mathrm{~Hz}$.

En los resultados del sistema 3 se observa que al encolar al tablero de partículas una lámina asfáltica mejora en todo el rango de frecuencias el Índice de Reducción Acústica y prácticamente elimina el efecto de coincidencia del tablero.
One possible way to improve reed panel insulation against air-borne noise is to use these materials in conjunction with wood products such as medium density fibreboard, MDF. Such systems could then be applied in partition walls, façades and roofs, providing suitable acoustic insulation against air-borne noise in housing. MDF was chosen here for its construction versatility and because it affords reed panels greater mechanical strength while reducing their permeability to the air and water in the system. Sixteen-mm thick MDF with a thermal conductivity of $\lambda=0.18 \mathrm{~W} / \mathrm{m}$. K was used in this study.

The acoustic test findings for different combinations of reed panels and MDF are discussed below. Figure 9 compares the sound reduction index values for the following systems: 1) MDF; 2) MDF with $5 \mathrm{~cm}$ thick reed panel backing; 3) MDF to which a (2mm thick and surface density of $3.5 \mathrm{~kg} / \mathrm{m}^{2}$ ) asphalt membrane was glued; 4) two MDF panels with a 5-cm thick reed panel sandwiched in-between. Systems 2, 3 and 4 exhibited substantially higher sound reduction indices than system 1 and reduced the coincidence effect of the particle board, whose critical coincidence frequency is around $1700 \mathrm{~Hz}$.

The results for system 3 show that when an asphalt membrane was glued to the particle board, the sound reduction index improved across the entire range of frequencies, practically eliminating the coincidence effect in the board. 


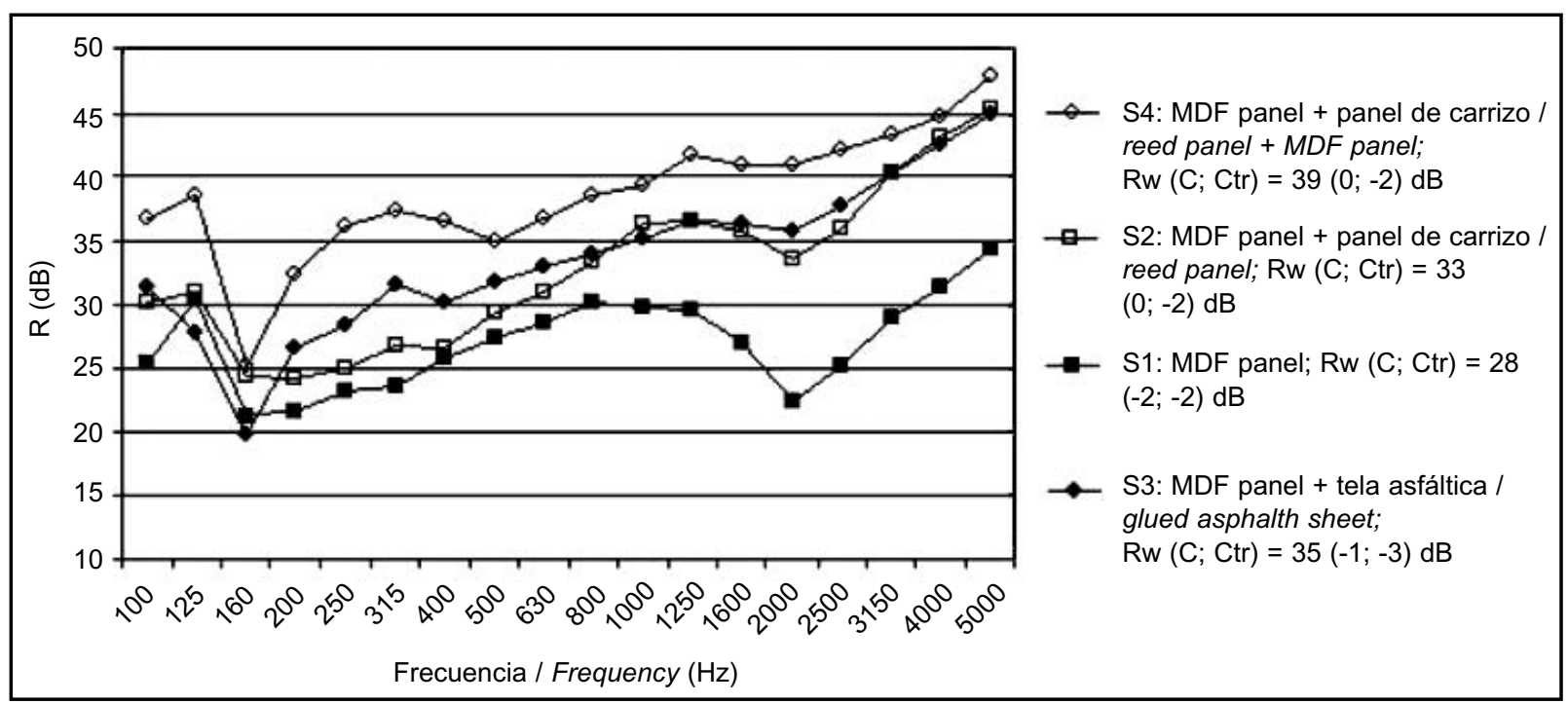

Figura 9. Gráficas de los índices de reducción acústica $\mathrm{R}$ de diferentes sistemas con un tablero de MDF.

Figure 9. Sound reduction indices, $R$, for reed panels attached to MDF.

El sistema 4 tiene un espesor de $82 \mathrm{~mm}$ y una masa por unidad de superficie de aproximadamente $30 \mathrm{~kg} / \mathrm{m}^{2}$. Presenta un Índice de Reducción Acústica que permite utilizarlo como partición entre recintos. La frecuencia de resonancia del sistema formado por los dos tableros se sitúa alrededor de $150 \mathrm{~Hz}$, si la distancia entre los dos paneles fuese mayor de $10 \mathrm{~cm}$, la frecuencia de resonancia del sistema sería inferior a $100 \mathrm{~Hz}$. La colocación en la cavidad del panel de carrizo elimina el efecto de coincidencia.

La Figura 10 muestra la comparación del Índice de Reducción Acústica del sistema de dos tableros DMF y panel de carrizo intermedio con otras particiones habituales en la edificación. El valor de la magnitud global $R_{W}+C$ en $\mathrm{dB}$, del sistema 4 es mayor que el de las paredes de
The sound reduction index found for system 4, which was $82 \mathrm{~mm}$ thick and had a surface density of approximately $30 \mathrm{~kg} / \mathrm{m}^{2}$, showed that it was apt for use as a partition wall. The resonance frequency of the system formed by the two boards was around $150 \mathrm{~Hz}$; if the distance between them had been $10 \mathrm{~cm}$, the resonance frequency would have been under $100 \mathrm{~Hz}$. Sandwiching the reed panel in the gap eliminated the coincidence effect.

Figure 10 compares the sound reduction index for system 4 (two MDF boards with a reed panel sandwiched in-between) to other types of partitions commonly used in buildings. The value (in $d B$ ) of the weighted $R_{W}+C$ for system 4 was greater than the value for an $8-\mathrm{cm}$ hollow

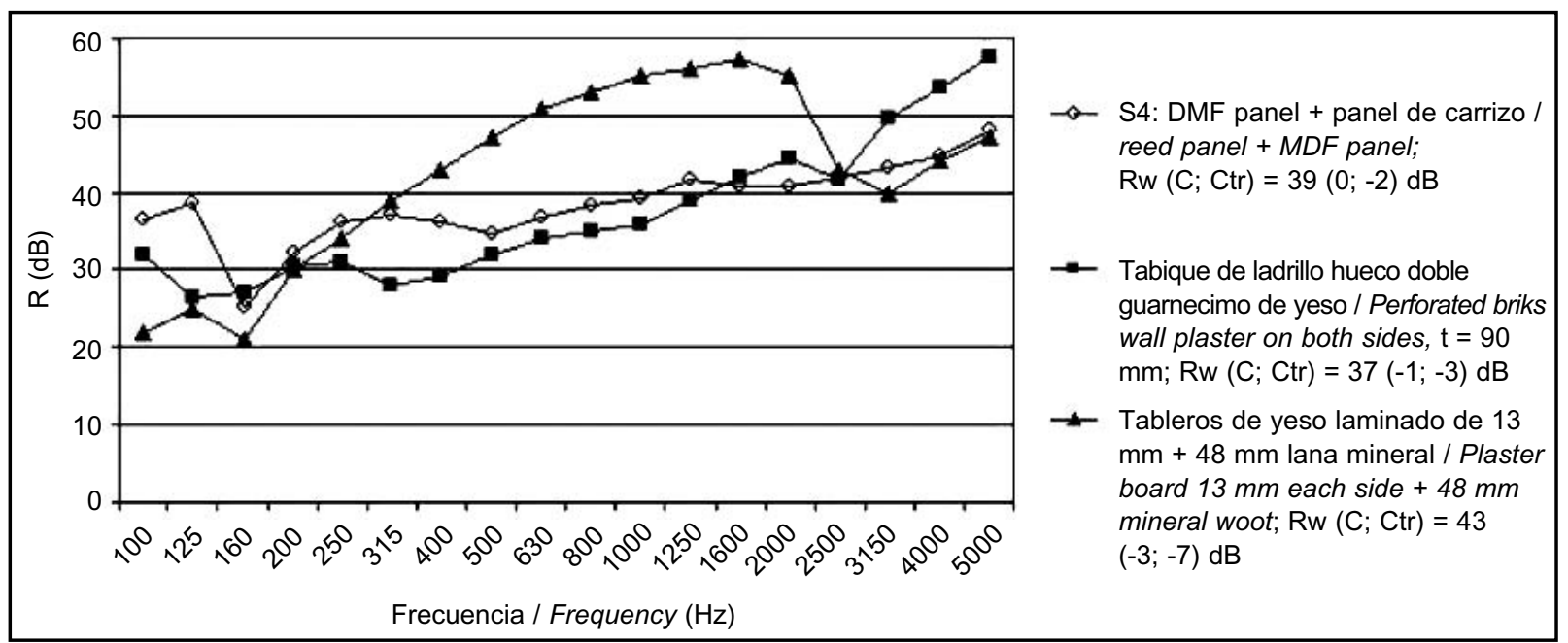

Figura 10. Comparación del Índice de Reducción Acústica del sistema de dos tableros MDF y panel de carrizo intermedio con otras particiones habituales.

Figure 10. Sound reduction indices for two MDF boards with a reed panel sandwiched in-between and two standard partitioning systems. 
ladrillos de hueco doble y del mismo orden que algunos sistemas de paneles de yeso laminado.

Los resultados del Índice de Reducción Acústica del sistema 3 muestran la posibilidad de utilizar este sistema como base para otros sistemas constructivos que tengan mejor Índice de Reducción Acústica, y que sean adecuados en fachadas y cubiertas. La colocación de la lámina asfáltica mejora la impermeabilización del sistema. Se realizaron ensayos acústicos con el sistema 3 trasdosándolo con una, dos y tres capas de carrizo. Los datos obtenidos se muestran en la Figura 11. Al añadir tres capas de carrizo, mejora al sistema base en $2 \mathrm{~dB}$ respecto a su protección frente al ruido de tráfico. brick wall and similar to the index for some plasterboard systems.

Further to the sound reduction index findings, system 3 could be used as a base for other construction systems whose higher sound reduction index makes them suitable for façades and roofs. The use of the asphalt membrane would enhance system weatherproofing. Sound tests were conducted with system 3 after covering it with one, two or three layers of reed. The findings are shown in Figure 11. Adding three layers of reed improved insulation performance against traffic noise by a full $2 d B$.

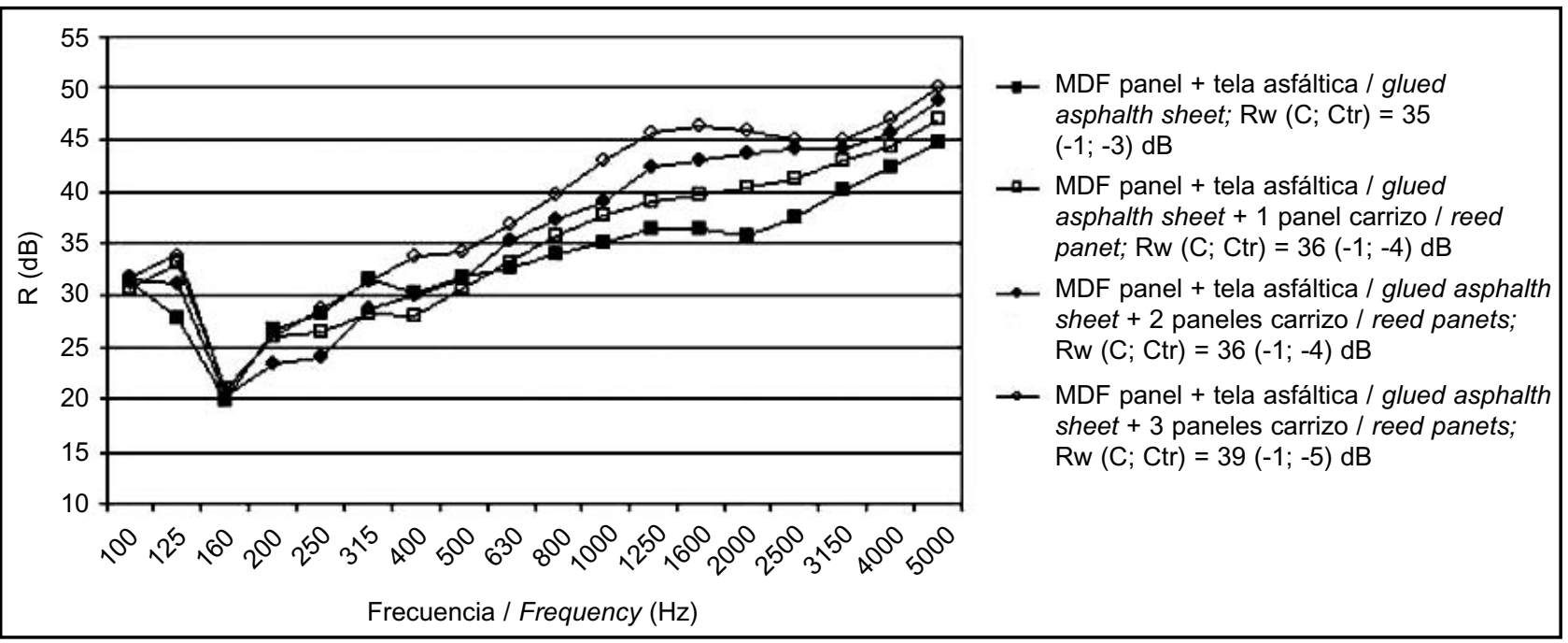

Figura 11. Índices de Reducción Acústica del sistema 3 trasdosado con capas de carrizo. Figure 11. Sound reduction indices for system 3 backed with reed panels.

Finalmente se ensayaron otros sistemas que tuviesen paneles de carrizo por las dos caras, que puedan utilizarse en fachadas y cubiertas, de forma que tengan un adecuado Índice de Reducción Acústica y al mismo tiempo reduzcan el tiempo de reverberación en un recinto. Los resultados obtenidos se muestran en la Figura 12. Es de destacar los valores del Índice de Reducción Acústica del sistema 4 al que se le han añadido un panel de carrizo por cada lado. Este nuevo sistema constructivo tiene un espesor de $182 \mathrm{~mm}$ y una masa por unidad de superficie de aproximadamente $46 \mathrm{~kg} / \mathrm{m}^{2}$. Este sistema es adecuado para fachadas y cubiertas de viviendas situadas en zonas donde el ruido de tráfico no sea elevado.

\section{CONCLUSIONES}

En la investigación desarrollada en este artículo se han caracterizado acústicamente sistemas constructivos ecológicamente sostenibles basados en paneles de carrizo, respecto a su absorción acústica e Índice de Reducción Acústica.
Finally, other systems designed for use in façades and roofs were tested with reed panels on both sides, to measure the resulting sound reduction index and reduce reverberation time in a room. The findings are shown in Figure 12. Note the sound reduction index values for system 4 after reed panels were added to each side. This new construction system, $182 \mathrm{~mm}$ thick and with a surface density of approximately $46 \mathrm{~kg} / \mathrm{m}^{2}$, would be apt for façades and roofs on buildings located in areas with moderate traffic noise.

\section{CONCLUSIONS}

The research discussed in this article studied the sound absorption and sound reduction index values for sustainable reed panel construction systems. 


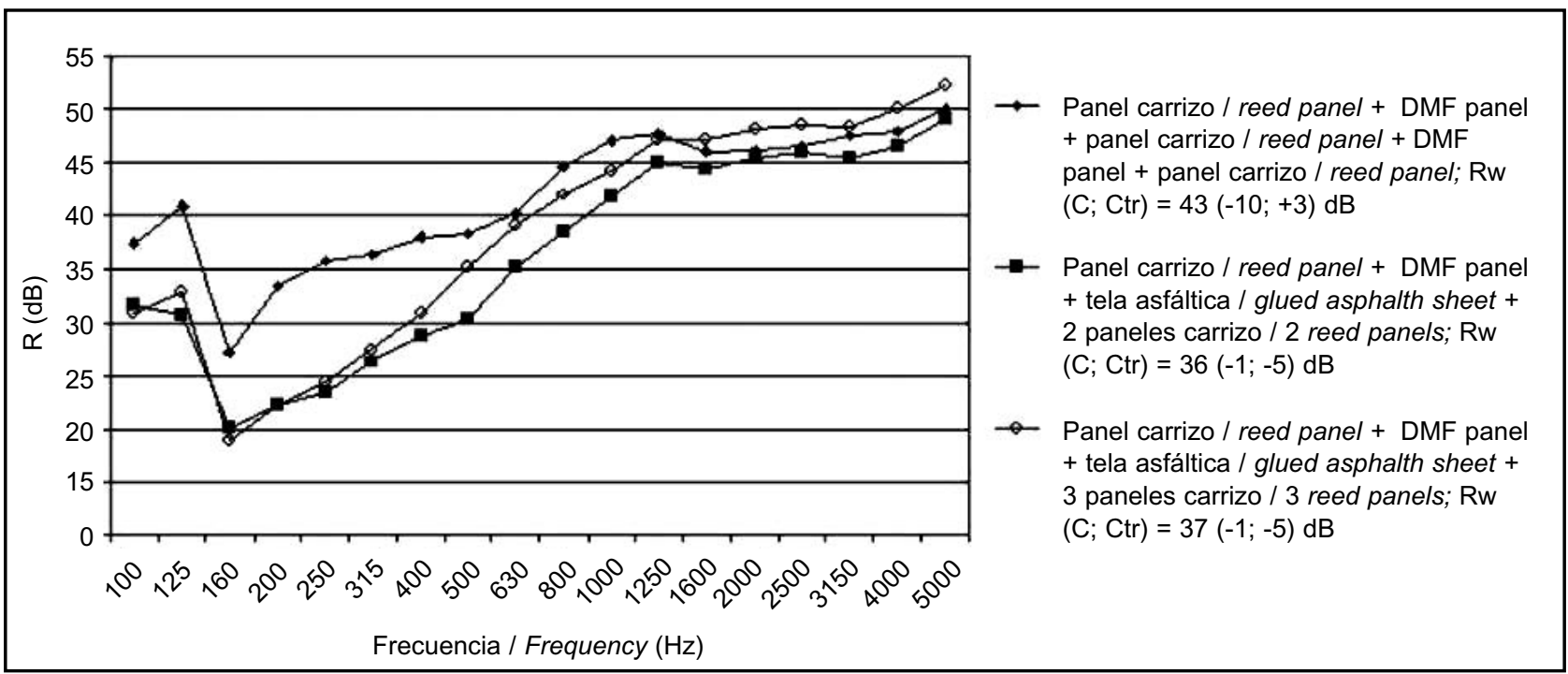

Figura 12. Sistemas constructivos con paneles de carrizo por ambas caras. Figure 12. Construction systems with reed panels on both sides.

Los resultados de los ensayos realizados muestran que los paneles de carrizo tienen una buena absorción acústica a medias y altas frecuencias, semejante a la de otros materiales o dispositivos absorbentes sonoros, pudiéndose utilizar trasdosado, como techo flotante, o como dispositivo absorbente suspendido.

Cuando está trasdosado a una superficie rígida, a medida que aumenta el espesor de los paneles, se incrementa el coeficiente de absorción acústica a frecuencias medias y bajas. A partir de la banda de frecuencia central de $1 \mathrm{kHz}$, el espesor de los paneles no influye en los valores del coeficiente de absorción acústica.

El uso de paneles de carrizo como sistema de acabado de las superficies interiores de un recinto (paredes, techos) puede reducir los niveles de presión sonora en el campo de reverberante y controlar el tiempo de reverberación del recinto.

Para los paneles de carrizo se ha calculado una correlación múltiple para determinar la relación entre el Índice de Reducción Acústica R como función de su masa por unidad de superficie $m^{\prime}$ y la frecuencia, $f$.

Los paneles de carrizo pueden ser utilizados como particiones interiores, en fachadas, cubiertas y barreras acústicas tanto en exteriores como en interiores de recintos.

La utilización conjunta de los paneles de carrizo con paneles DMF y láminas asfálticas mejoran de forma importante el Índice de Reducción Acústica de los sistemas ensayados. Además, algunas soluciones permiten reducir los niveles de presión sonora en el campo de reverberante y controlar el tiempo de reverberación del recinto.
The test findings showed that reed panels absorb medium and high frequency sound about as well as other sound absorbent materials and can be used as backing, floating ceilings or suspended absorbers.

When these panels are attached to a stiff substrate, their sound absorption coefficient at low and mid frequencies rises with panel thickness. At centre frequency bands of $1 \mathrm{kHz}$ or higher, panel thickness has no impact on the sound absorption coefficient values, however.

The use of reed panels as a finish on walls and ceilings may suffice to reduce sound pressure levels in the reverberant field and control reverberation time in a room.

Multiple correlation analysis was performed for reed panels to determine the relationship between their sound reduction index, $R$, and surface density, $m^{\prime}$, and frequency, $f$.

Possible uses for reed panels include partition walls, façades, roofs and both outdoor and indoor sound barriers.

The joint use of reed panels, MDF and asphalt membranes substantially improves the sound reduction index of the systems tested. Moreover, some solutions reduce the sound pressure in the reverberant field and control room reverberation times. 
Los resultados obtenidos en los ensayos realizados abren nuevas líneas de investigación con diferentes combinaciones de materiales ecológicamente sostenibles.
The present findings suggest new lines of research with other combinations of sustainable materials.

\section{REFERENCIAS / BIBLIOGRAPHY}

(1) Chilekwa, V.; Sieffert, G.; Egan, C.A.; Oldham, D.: "The acoustical characteristics of reed configurations". Euronoise 2006, Tampere, Finland, May 30-June 1, 2006, en CD-ROM.

(2) European Standard EN 354: 2003. "Acoustics - Measurement of sound absorption in a reverberation room".

(3) Jiménez-Espada, M. et al.: "The acoustical potential of reed panels for partitions in sustainable construction". 19th International Congress on Acoustics, Madrid, Spain, September 2-7, 2007, In CD-ROM.

(4) EN ISO 140-3: 1995. "Acoustics. Measurement of sound insulation in buildings and building elements. Part 3: Laboratory measurements of airborne sound insulation of building elements".

(5) EN ISO 717-1:1996. "Acoustics. Rating of sound insulation in buildings and building elements. Part 1: Airborne sound insulation". 